\title{
Views of Social Studies Teachers on E-Learning
}

\author{
Hüseyin $\mathrm{EROL}^{1}$ \\ ${ }^{1}$ Adıyaman University Faculty of Education Social Studies Education, Adiyaman, Turkey \\ Correspondence: Hüseyin EROL, Department of Social Studies, Faculty of Education, University of Adiyaman, \\ Adiyaman, Turkey. E-mail: h02.erol@hotmail.com
}

Received: January 15, 2021

Accepted: April 6, 2021

Online Published: May 17, 2021

doi:10.5539/ies.v14n6p82

URL: https://doi.org/10.5539/ies.v14n6p82

\begin{abstract}
Online educational platforms have recently been used to compensate for educational activities that have been interrupted all around the world due to the pandemic during the year 2020. This study was conducted to reveal reflections of e-learning on social studies courses. Among qualitative research designs, the case study method was used. The data were collected using semi-structured interview. The study group consisted of 27 social studies teachers working in public secondary schools in Adiyaman province of Turkey. Those teachers were determined based on purposeful sampling method. These teachers were determined based on non-random purposeful sampling criterion. They were interviewed considering that they used the online education platform intensively during the pandemic and had the necessary experience to make evaluation in this regard. The data were collected between September and November 5, 2020. The data were analysed using inductive analysis. The study results showed that social studies teachers could not literally adapt to e-learning activities due to their lack of knowledge about using computers. They did not internalize virtual education but had a perception that such education could be used as a supportive one for face-to-face education or for review. The study found that the EBA (Education Information Network), the most comprehensive online educational platform in Turkey, could not literally meet the needs in terms of infrastructure and content. Teachers endeavoured to adapt to e-learning during the pandemic and they welcomed admiringly the preparations made by the MEB (Ministry of National Education) despite the deficiencies therein. The majority of teachers stated they did not receive any course related to e-learning during their undergraduate education. In-service e-learning training can be provided to social studies teachers. E-learning courses can be included in the programs in education faculties. The Ministry of National Education can enrich its infrastructure.
\end{abstract}

Keywords: education information network, e-learning, social studies

\section{Introduction}

The 21 st century has started to change people's life radically with its dizzying speed in information and communication technology. It is possible to feel this change in every area of life. In particular, with the evidence of individual learning in today's world, education has shifted from being teacher-centered to being student-centered, which is implementable independent of physical environment. Developments in information and communication technologies cause this (Aslan, 2006). Proliferation of network-based technology has led to adaptation of mutual interaction-based virtual learning models (Soydan, 2011). Among these models, e-learning which is flexible and does not require classroom environment and has no time limit comes into prominence (Kantoğlu, 2012). E-learning can be defined as sharing and storing knowledge on interaction basis, education that can be updated when needed, and being delivered to users via Internet (Rosenberg, 2000). Considering its facilities, e-learning detracts students from boring atmosphere of classroom. Thus, they can learn better as they feel freer. This allows students to intervene in the system according to their speed of understanding (Seferoğlu, 2007). This also allows them to repeat a topic without any limitation. E-learning boosts interaction between teacher and students. The teacher can have a conversation with the students and ask them questions and answer their questions as well (Cheong, 2002). Students' motivation increases when they are offered interactive interface and course content. Besides advantages of e-learning, there are also disadvantages such as becoming asocial due to spending too much time on computer, students having problem in participating courses due to their poor technology literacy and skills, lack of material and equipment for e-learning, problems faced by students while accessing to courses, students having problems in planning their learning period, postponing learning, thus facing problems such as not completing the course subjects (Aytaç, 2006; Seferoğlu, 2007; Uşun, 2004; Yalın, 2008). There are many online 
e-learning platforms both in Turkey and around the world. Among these are Khan Academy (2020) free of charge with more than 40 million users; Udemy Inc. (2020) entering into service in 2009, offering rich videos with varied contents; edX Inc. (2020) providing services with more than 2500 video contents and collaborating with the most prominent universities around the world; and Coursera Inc. (2020) providing services to 56 million people and collaborating with many international companies and universities. Rain Classroom (University of Macau, 2018) that has been used in Chine since 2016 is known to be the most developed and effective online educational platform in the country. There are more than 19 million people registered to this platform. However, in Turkey, there are different educational portals divided into formal and informal ones. The most comprehensive one is Education Information Network known as EBA, which comprises more than 12 million students enrolled in public schools. This platform was set up to support material use and to integrate technology into education by using information technology tools (Millî Eğitim Bakanlığı, n.d.). Besides being used together with face-to-face education, online education platforms offer an important alternative used due to obligatory reasons arising locally or globally from time to time.

Covid-19 virus which had global effects in the year 2020 and then rapidly became pandemic has taken part on the agenda. To prevent the expansion of Covid-19, most schools in more than 190 countries around the world had to suspend their activities and more than $91 \%$ of students were adversely affected by this suspension (Miks \& Mcllwaine, 2020; UNICEF, 2020). Many countries endeavour to escape this process with minimum loss in educational activities by use of online educational platforms that are tried to be integrated rapidly to educational systems of the countries. An online educational platform has been used to maintain training activities in China, which is known to be the source of the Covid-19 outbreak. Although educational institutions in Europe, another badly affected region by the pandemic, temporarily suspended their education at first, they had to take permanent actions as the pandemic reached dangerous levels. In the USA, the most affected country by the pandemic, some educational institutions canceled face-to-face courses, while some began to provide online education. Notable universities in the USA offered online educational platforms to the service of users as in China (Yamamato \& Altun, 2020). UNICEF has set up remote education called "Learning Passport" to ensure continuity of students and support education and science ministries of different countries by offering remote education options so that parents, caretakers, and teachers can access sources during quarantine process (Miks \& Mcllwaine, 2020; UNICEF, 2020). With the first incidence of Covid-19 in Turkey in the second week of March 2020, the government suspended the primary, secondary and higher schools for a short while; but short after the rapid expansion of the pandemic, all other educational institutions were closed too. Thus, the universities and private schools used the infrastructure of online educational programs to continue their education. The Ministry of National Education used its own online educational network, Education Information Network (EBA), and started its remote educational activities quickly. This study intended to analyse the current situation based on the teachers' evaluation on the focal point of implementing remote education in Turkey during Covid-19 pandemic. For the research, the effect of the pandemic on the process will be examined in terms of social studies through interviews with social studies teachers. The results to be obtained from the study can shed light on making evaluation on the place of e-learning in social studies teaching and e-learning application usage of social studies teachers. Thus, the author sought for answers to the following questions. The problem statement of the study was determined as "What are the thoughts of social studies teachers about the effect of e-learning on social studies course applied to resolve the setback in educational system interrupted by Covid-19 pandemic in 2020?"

1) Does EBA (Education Information network) meet the needs of social studies? How would you score the contents?

2) What do you think on the instruction of social studies through e-learning?

3) What could be more attractive for students in teaching social studies through e-learning? What are your suggestions?

4) Did you ever receive any course related to e-learning during your undergraduate or postgraduate education?

5) How would you rate your e-learning performance?

6) Did you make any preparation individually for e-learning during the pandemic? Can you explain it?

7) How do you evaluate e-learning preparations made by the MEB?

\section{Method}

This study used qualitative research method to investigate social studies teachers' views on e-learning. Perceptions and events try to be set forth with a realistic and holistic approach in their own environment in qualitative research where the data are collected through observation, interview and document analysis (Creswell, 2007; Yildırım \& 
Şimşek, 2011). The case study method was used in this study. Case study is a method thoroughly examining a certain case to explain the phenomena supervening in their own natural environment (Hancock \& Algozzine, 2006; Merriam, 2013). The appropriate method for this study was believed to be case study since teachers' views were analyzed regarding the place of e-learning in social studies teaching.

Study Group:

The study group of this research consisted of 27 social studies teachers working in public secondary schools in Adiyaman province of Turkey and selected by criterion sampling among non-random purposeful sampling methods. The reason that this study targeted social studies teachers is to determine the place of e-learning in teaching social studies and to find out teachers' views on this new learning style. Table 1 shows demographic attributes of teachers in the study group.

Table 1. Demographic attributes of social studies teachers

\begin{tabular}{ccc}
\hline Gender & $\mathrm{F}$ & $\%$ \\
\hline Female & 11 & 40.74 \\
Male & 16 & 59.25 \\
\hline
\end{tabular}

Of the participants, $40.74 \%$ were female and $59.25 \%$ were male teachers. Male teachers in the study group were coded as "MT" and female teachers were coded as "FT" in analysing the interview forms.

Data Collection Tools:

The questions were prepared by the researcher and the data were collected using semi-structured interview. The related literature was reviewed, and the questions were prepared by the researcher while developing the form. The reason for using semi-structured interview is that this method is not hard as structured interviews and it is flexible as well (Karasar, 2007). Semi-structured interview helps to determine the similarities and differences between answers obtained from the participants and to make comparisons (Balc1, 2015; Metin, 2015). Seven questions about the research problem were included in the interview. Each question formed sub-problem of the research. The researcher elaborated the interview form carefully, made the questions clear without directing the participants. After the interview questions were prepared, it was finalized getting opinions of three experts.

Data Analysis:

The data were analysed using inductive analysis. Such analysis is used in collecting, analysing and interpreting similar data regarding a topic (Akgün, Büyüköztürk, Demirel, \& Karadeniz, 2008; Mayring, 2000; Yıldırım \& Şimşek, 2011). This method discovers the concepts underlying the data through coding and the relationships between these concepts (Miles \& Huberman, 1994; Yıldırım \& Şimşek, 2011). The data from this study were analysed by comparison of the data obtained in written form at first. In the second step, the researcher and another lecturer, expert in qualitative research, coded the data independently. For reliability, the Reliability = Consensus/Consensus + Disagreement X 100 formula was applied on the codes formed by the two researchers (Miles \& Huberman, 1994). The match between the two scorers was $85 \%$. Since the match rate $70 \%$ and above is deemed sufficient, reliability was ensured in terms of data analysis.

\section{Results}

This section includes the findings obtained from the study. The views of social studies teachers were analysed and interpreted regarding EBA and its contents, instruction of social studies via e-learning, teachers' individual preparations for e-learning during the pandemic, their suggestions for making EBA more attractive, preparations of the MEB for e-learning activities, and self-assessment of performance in this process. 
Table 2. Views of social studies teachers about how EBA meets the needs and its contents

\begin{tabular}{lll}
\hline Themes & Sub Themes & Codes \\
\hline & Those having a positive attitude & Contents are satisfactory \\
\cline { 3 - 4 } & & Not satisfying exactly \\
& Should be enriched visually \\
& & Need to be updated frequently \\
& Partly satisfying & Could be obscure sometimes \\
\cline { 2 - 4 } & & Problematic concerning feedback \\
\hline \multirow{2}{*}{ Those having a negative attitude } & Not applicable to today's educational philosophy \\
& & Creates virtual perception \\
& & Contents are insufficient \\
& & Materials are limited in the system \\
& & Insufficient regarding assessment and evaluation \\
\hline
\end{tabular}

Table 2 shows social studies teachers' views about how EBA meets the needs the contents of EBA. Majority of the social studies teachers stated that EBA partly met the needs. MT3: "I cannot say that EBA exactly meets all educational needs, I think the contents should be updated frequently. Some animations and graphics are not updated." In this regard, teachers criticized insufficiency of EBA in terms of its update issues and content and its perception of virtuality evoked in the students. MT9: "I think EBA is insufficient in terms of learning outcomes, videos and written materials." Teachers who had a positive attitude stated that EBA was sufficient in meeting the needs and the contents were prepared supportively for teaching social studies. FT8: "I think videos, work sheets and learning outcome tests in EBA can be used as effective teaching aids in teaching social studies." EBA, which is used intensively during the pandemic, is expected to cause major changes in the Turkish education system. Making the EBA platform more practical with the enrichment of the contents of social studies may bring more beneficial outcomes for teachers.

Table 3. Views of social studies teachers about the instruction of social studies through e-learning

\begin{tabular}{|c|c|c|}
\hline Themes & Sub Themes & Codes \\
\hline \multirow{14}{*}{ 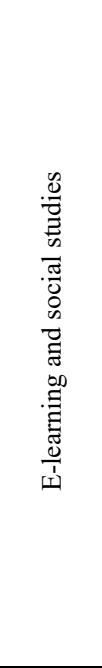 } & \multirow{5}{*}{$\begin{array}{l}\text { It is inappropriate to the spirit of the } \\
\text { course }\end{array}$} & It is inappropriate as social studies course entails face-to-face interaction \\
\hline & & Social studies course does not achieve its goal without effective interaction \\
\hline & & I do not find it appropriate since social studies address to affective behaviours \\
\hline & & It is not applicable to teach certain skills in social studies \\
\hline & & $\begin{array}{l}\text { It is not suitable for the objective of the course since the course focuses on human and } \\
\text { society }\end{array}$ \\
\hline & \multirow{2}{*}{ It serves the purpose of the course } & It has much contribution to the course \\
\hline & & It is applicable to social studies instruction \\
\hline & \multirow{7}{*}{ It can be an alternative } & It can be used for repetition \\
\hline & & It helped me to understand better the face-to-face teaching \\
\hline & & It is helpful to provide information briefly and quickly \\
\hline & & It cannot replace face-to-face education but can be used \\
\hline & & $\begin{array}{l}\text { Since social studies course focuses much on theories, e-learning can be used as an } \\
\text { alternative }\end{array}$ \\
\hline & & It can be used if rich content and educational games are included \\
\hline & & Even if it is insufficient when used alone, it still can be used \\
\hline
\end{tabular}

Table 3 shows the views of social studies teachers about the instruction of social studies through e-learning. Teachers seem to have different attitudes towards the instruction of social studies using e-learning. In this regard, teachers who have a positive attitude believe that e-learning is applicable to social studies instruction and has contributions to the course. MT16: "E-learning has become indispensable in today's world. Visual materials offered in e-learning help me to teach the lessons better. I believe it is both beneficial and economic in delivering knowledge briefly and quickly." Teachers who have a negative attitude towards teaching social studies through e-learning might have thought that it is inappropriate to the spirit of the course to teach social studies since it entails effective communication skills and because social studies course addresses to affective behaviours in some aspects. MT5: "E-learning does not provide concrete information in social studies and it is insufficient in 
topics that give particular importance to visuality and need to concretize things. Social studies course entails constant communication and interaction and comprises social issues that require discussion and opinion exchange. Thus, I do not think that e-learning can gain a permanent seat in teaching social studies." Teachers who stated that e-learning could be deemed a supportive and alternative method to face-to-face education in social studies reflected that e-learning might become interesting if the contents were enriched and e-learning contents could be used for course repetitions. FT12: "On condition that it does not adhere to direct instruction, I believe that teaching social studies through e-learning will be more efficient with rich content and educational games." It is obvious that e-learning has not gain a seat among social studies teachers in a way to unseat face-to-face education, but to be integrated into educational system and be used appropriately.

Table 4. Suggestions of teachers in terms of making e-learning instruction of social studies attractive

\begin{tabular}{|c|c|c|}
\hline Themes & Sub Themes & Codes \\
\hline \multirow{12}{*}{ 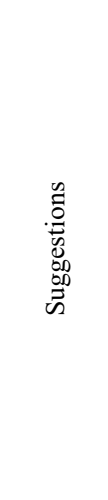 } & \multirow{7}{*}{ Enjoyable content } & Comic strip \\
\hline & & Activity \\
\hline & & Animation \\
\hline & & Cartoon \\
\hline & & Clips \\
\hline & & Games \\
\hline & & Caricature \\
\hline & \multirow{5}{*}{ Informative content } & Visuals \\
\hline & & Interactive activities \\
\hline & & Videos \\
\hline & & Online exams \\
\hline & & Slides \\
\hline
\end{tabular}

Table 4 provides the views of social studies teachers about the contents that should be added into EBA platform to make e-learning more attractive. The teachers stated that the platform should include more activities (comic strips, cartoons, animations, clips, etc.) which entertain students and contribute to their learning. FT6: "Since social studies course focuses on theories and learning by heart, it can be more attractive if it is supported with enjoyable activities." Besides that, teachers provided other suggestions such as increasing videos, visuals and slides, including interactive activities, and making assessment and evaluation at national and international level in e-exam format can increase students' motivation. MT7: "I believe that visual images are necessary for social studies. At that point, the course can be more efficient if supported with activities addressing to visual memory instead of standard test or exercises." Social studies teachers consider their students' age and suggest that more concrete items should be included in the course. This suggestion seems to be logic considering that majority of the secondary school students newly take steps into abstraction due to their developmental period. The frequent use of visual items that stay in mind longer may have more efficient outcomes in terms of teaching social studies.

Table 5. Statements of social studies teachers on whether they received e-learning courses during undergraduate or postgraduate education

\begin{tabular}{|c|c|c|}
\hline Themes & Sub Themes & Codes \\
\hline \multirow{2}{*}{ 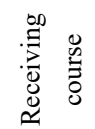 } & Yes & I received course during my undergraduate education \\
\hline & No & I did not receive any course \\
\hline
\end{tabular}

Table 5 shows the statements of social studies teachers on whether they received e-learning courses during undergraduate or postgraduate education. Majority of the teachers did not receive any course related to e-learning. FT3: "I did not receive any course related to e-learning during my undergraduate education. I take part in e-learning activities through my own means and efforts." Only three out of the teachers received course related to e-learning. MT10: "I received courses on e-learning during my undergraduate education. However, I think they were not sufficient because they focused more on theories and there were very few practices." This finding reveals that undergraduate and postgraduate educational programs in Turkey should be investigated with regard to e-learning. The lack of e-learning course in university programs where many different courses are 
offered is an important setback. If the teachers had received any course on e-learning during their education, some of them might have now fewer preconceptions against e-learning activities.

Table 6 . Views of social studies teachers regarding self-assessment on e-learning

\begin{tabular}{|c|c|c|}
\hline Themes & Sub Themes & Codes \\
\hline \multirow{9}{*}{ 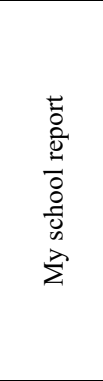 } & \multirow{4}{*}{ My performance is good } & I can use it effectively and actively \\
\hline & & I can use it without facing any problems \\
\hline & & I am well prepared to adapt to the process \\
\hline & & I have good skills at using computer, I have no problems \\
\hline & \multirow{4}{*}{ My performance is not at a desired level } & I have difficulty as I did not receive any course about e-learning \\
\hline & & I think I am not well equipped \\
\hline & & I feel I have deficiencies \\
\hline & & I can say I am good even not so good as in face-to-face education \\
\hline & My performance is not good & My performance is not good at e-learning \\
\hline
\end{tabular}

Table 6 shows the data concerning self-assessment of performance of social studies teachers on e-learning. The majority of them found their individual performance to be insufficient. That the teachers found themselves in a virtual educational environment with the sudden outbreak of pandemic, they were not prepared, and most importantly they felt unequipped are the reasons for this. MT12: "Since I did not receive any course on e-learning, I face problems during remote education." FT5: "I feel I am inadequate regarding online content creation or development. "Teachers who find their individual performance good seem to be the ones who quickly adapt to the process and have advanced computer skills. MT14: "I have gained knowledge about e-learning from online courses offered by the MEB and several videos regarding e-learning." Only one teacher found her performance insufficient. FT1: "I am not satisfied with my performance. I could not adapt myself to virtual education. My bad computer skills cause me disadvantage.

Table 7. Views of social studies teachers on the preparations they made for e-learning process

\begin{tabular}{lll}
\hline Themes & Sub Themes & Codes \\
\hline & & I prepared questions \\
& I improved my computer skills \\
& I tried to access online course contents \\
& I read academic publications about e-learning \\
& I watched educational videos \\
& I gave trial lectures \\
& I prepared lecture notes \\
& I participated in online courses of the ministry \\
& I prepared activities \\
& I shared my documents with my students on WhatsApp \\
& I explored the books in z-kitap (enriched books) \\
& I prepared slides \\
\hline \multirow{2}{0.0}{} & I supposed to be subjected to in-service training \\
& I did not make any preparation & I did not make any preparation as I kept the previous documents \\
\hline
\end{tabular}

Table 7 shows the views of social studies teachers on the preparations they made for e-learning process. The teachers mostly prepared course notes, watched online course samples, and tried to develop their computer skills during the preparation for the process. MT2: "I searched how e-learning is carried out. I watched videos about that. I prepared on the documents I would use in my courses. "Some teachers seem to have shared the documents they prepared using the social media and discovered e-learning related tools. FT10: "I analyzed the z-kitap and online contents. My previous experience in using interactive board contributed me too much in e-learning." Teachers who did not make any preparation supposed that the ministry would arrange training courses for them regarding e-learning. MT15: "I did not make any preparation since I thought the MEB was going to provide us with in-service training for e-learning." Teachers seem to have been prepared for e-learning, which began with the school closure during the pandemic, because of their professional and moral responsibilities. They try to adapt and 
contribute to the process by using their knowledge and experience in a virtual educational environment.

Table 8 . Views of social studies teachers on e-learning preparations made by the MEB (Ministry of National Education)

\begin{tabular}{|c|c|c|}
\hline Themes & Sub Theme & Codes \\
\hline \multirow{13}{*}{ 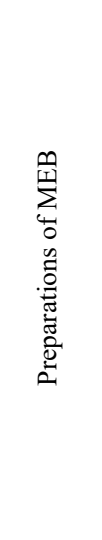 } & \multirow{4}{*}{ It met my expectations } & It manages the process well \\
\hline & & It has a good infrastructure \\
\hline & & It has rich content \\
\hline & & Live courses and the limited Internet provided are important \\
\hline & \multirow{3}{*}{ It is good but not sufficient } & I appreciate but do not find it sufficient \\
\hline & & The contents are useful but have access problems \\
\hline & & It has deficiencies besides amelioration \\
\hline & \multirow{6}{*}{ There is no good preparation } & Students who do not have Internet are not considered \\
\hline & & I do not find it sufficient \\
\hline & & Constant access problems demotivate me \\
\hline & & It does not offer equality of opportunity \\
\hline & & The infrastructure is insufficient \\
\hline & & The contents are insufficient \\
\hline
\end{tabular}

Table 8 shows the views of social studies teachers on e-learning preparations made by the MEB during the pandemic. Although teachers appreciated the preparations made by the MEB, they found some deficiencies. Some of them criticized that not all the students throughout the country are able to access to EBA and the founders of this system ignore socio-economic level of the public. FT9: "I like the preparations made by the MEB. However, all students need to have a personal computer and Internet so that e-learning can reach its goal. Unfortunately, many students of mine do not have these sources due to socio-economic levels of their families. This hinders educational activities." In the interviews with the teachers, this appeared to form a common opinion in teachers as to the breach of equal opportunity in education. In particular, the students who have no possibility to connect to the Internet cannot be integrated into the system. FT7: "It is not fair to expose a school in a disadvantaged region and a school in the city center of Ankara to the same application. MEB should have considered regional differences while organizing its studies." Teachers who find preparations made by the MEB sufficient stated that the process was managed well and communication with students was established to some extent thanks to live courses on EBA. MT1: "I like e-learning preparations made by the MEB. I can see the ministry can bring fast solutions to the troubles emerging. In particular, being offered live courses increases my motivation."

\section{Discussion}

The results of the study showed that social studies teachers have different views on the contents of EBA (education information network) and its way of meeting educational needs. The majority of teachers thought that EBA can partly meet educational needs which are necessary for social studies. They also had a common view that EBA needs frequent update. Provided that EBA corrects the deficiencies of content, teachers may become more satisfied. Teachers with a negative attitude pointed out that e-learning cannot meet the needs in providing skills for effective communication which is necessary in social studies course. Some of the teachers believed that virtual learning environment does not serve the purpose of social studies course. Teachers with a positive attitude, on the other hand, stated that EBA has an efficient infrastructure in meeting educational needs of the students during the pandemic and the contents designed by EBA are sufficient and supportive for this type of education. Şahin and Erman (2019) stated that history teachers had positive attitude towards EBA as they believed it conformed to the course outcomes by addressing to more than one sense organ. Yerli (2018) stated that social studies teachers had a positive attitude in general towards EBA platform stating that EBA is beneficial and providing convenience to teachers during learning and teaching. Aksoy (2017) found that teachers mostly rated EBA as "partly effective and effective" in terms of learning and teaching.

This study revealed that a good part of social studies teachers thought e-learning on social studies courses could only be used as an alternative to face-to-face education. To resolve all deficiencies in education caused by the Covid-19, e-learning will promote its functionality and become the main learning structure with the contribution of new technologies and systems in the near future with lessons learned from global experiences following the rapid transition to digital learning environment (Yamamato \& Altun, 2020). This study showed that teachers who had a 
positive attitude towards teaching social studies through e-learning believed e-learning to be contributing to the instruction of social studies. However, those who had a negative attitude believed that e-learning could not gain a seat because the system is used instantly and densely by many users; teachers being accustomed to traditional teaching methods resist to change their habits; and additionally, some teachers prejudge against e-learning since they do not have the necessary computer skills to teach a lesson.

The social studies teachers reflected that enjoyable activities, videos, animations or clips could make EBA more attractive for social studies students and help them to overcome the perception that the social studies course is boring and full of theory and learning by heart. Teachers preferred the contents by which their students could learn while having fun, thinking their age levels. Establishing interaction in attracting students via e-learning and ensuring the continuity of their motivation provides vital advantages. This will absolutely reflect positively to students' learning performances (Çakır, 2012). Çakmak and Taşkıran (2017) stated that EBA could be used more effectively only when its infrastructure was reinforced, and its content was enriched.

This study showed that majority of social studies teachers did not receive any course on e-learning during their undergraduate or postgraduate education. Teachers participated in e-learning activities by trial and error learning or benefiting from experienced teachers during the pandemic. The study results showed that only three out of the teachers received course related to e-learning during their undergraduate education. This shows that there should be an immediate update for e-learning in educational programs of the faculties in Turkey. The interviews with the teachers showed that teachers, except for a course in which they were taught basic computer skills during their studies, did not receive any extra course in the related field. Aydemir (2011) found that 83.3\% of teacher candidates registered to geography teaching program in the faculty of education did not receive any course on e-learning. Of the participants, 93.3\% demanded training on e-learning. Based on the results of this study, if the teachers had received the necessary training on e-learning during their previous studies, the results of the study could be different now.

The majority of teachers stated to find their performance on e-learning partly sufficient. This may have been a result of their opinion that they did not have the necessary skills of using computer and online programs. Facing problems initially in adapting to virtual education environment where teachers were driven due to the sudden pandemic in 2020 may have caused them to think that they did not have the necessary skills on producing online contents or using them. Soydal, Alır, and Ünal (2012) suggested that academic personnel should be trained on e-learning. Coşkun, Özeke, Budakoğlu, and Kula (2018) found that lecturers were not literally prepared to e-learning and they needed to increase their intention to use e-learning platforms. Can (2020) underlined that non-inclusion of teachers in the infrastructure of EBA actively should be considered and brought into the agenda. In the current study, teachers, quickly adapting to e-learning process and having high skills of using computer rated their performance to be sufficient. Considering that primary and secondary school students need to be guided by their teachers in remote education, teachers should necessarily be integrated into the system quickly. Burke and Dempsey (2020) revealed that teachers in Ireland did not have the necessary skills for remote education and they had several difficulties in using computers. The results obtained from other studies support the results of this study.

Considering the preparations made by the teachers who took part in this study regarding e-learning, they mostly tried to increase their computer skills so as to adapt to the process, watched online course contents, and created document archives to use in their courses. Teachers who had documents before did not do any preparation for e-learning activities. On the other side, some teachers supposed that the MEB would provide them trainings for e-learning, so they did not make any preparation. Due to the mission of teaching, majority of the teachers felt responsible and did not want to meet their students unprepared, thus they underwent vigorous efforts to get prepared. This is important for teachers to show the respect for their profession.

Although there are deficiencies in the preparations made by the MEB for e-learning during the pandemic, the teachers welcomed the preparations made. The main problems faced in connecting to the system were criticized much by the teachers. Besides that, another important criticism was that not all students could access to EBA and no alternative solutions were generated regarding this. The authority that created this system should have known that some students would not have the possibility to connect to the Internet in every corner of a developing country like Turkey, they should have considered this to take the necessary precautions. Teachers commonly thought that this would harm the equality of opportunity in education. Teachers who thought that e-learning process was managed well were determined to be those who found sufficient the preparations made by the MEB. The teachers agreed on the point that the opportunity of live courses in EBA was appreciable. P1nar (2020) found out that students feel like they are at school thanks to live courses despite the lack of duration allocated to the live courses in EBA. It seems that live courses have resolved, to some extent, communication problems between students and teachers due to the pandemic. In the following are some suggestions based on the findings of the 
study. In-service training should be provided to teachers regarding e-learning. Infrastructure of EBA should be reinforced in terms of software/hardware. The necessary tools and equipment should be provided to students so that all students throughout the country can access to e-learning activities.

\section{References}

Aksoy, N. (2017). EBA (educational information network's) intended use, problems and solutions (MEd dissertation, Kahramanmaraş, Sütçü İmam University).

Aslan, Ö. (2006). New Way of Learning: E-Learning. Firat University Journal of International Social Sciences, 16(2), 121-131

Aydemir, D. N. (2011). E learning in education of geography (MEd dissertation, İstanbul, Marmara University).

Aytaç, T. (2006). Eğitimde bilişim teknolojileri [Information technologies in education]. Ankara, Turkey: Asil Yayınları.

Balc1, A. (2015). Sosyal bilimlerde araştırma [Research in social sciences]. Ankara, Turkey: Pegem.

Burke, J., \& Dempsey, M. (2020). COVID-19 Practice in primary schools in Ireland report. Ireland: National University of Ireland Maynooth. Retrieved from https://www.into.ie/app/uploads/2020/04/COVID-19Practice-in-Primary-Schools-Report-1.pdf

Büyüköztürk, Ş., Kılıç, Ç. E, Akgün, Ö. E, Karadeniz, Ş., \& Demirel, F. (2008). Bilimsel araştırma yöntemleri [Scientific research methods]. Ankara, Turkey: Pegem Akademi.

Çakır, H. S. (2012). Increasing interaction with content design in e-learning (PhD dissertation, İstanbul, Marmara University).

Çakmak, Z., \& Taşkıran, C. (2017). Views of social studies teachers on education information network (eba) platform. International Journal of Turkish Education Sciences, 9, 284-295.

Can, E. (2020). Coronavirüs (Covid-19) Pandemisi ve pedagojik yansımaları: Türkiye'de açık ve uzaktan eğitim uygulamaları. [Coronavirus (Covidien-19) pandemic and pedagogical implications: open and distance education applications in Turkey]. $A U A d, 6(2), 11-53$.

Cheong, S. C. (2002). E-learning-a providers prospective. Internet and Higher Education, 4, 337-352. https://doi.org/10.1016/S1096-7516(01)00075-6

Coşkun, Ö., Özeke V., Budakoğlu, I., \& Kula S. (2018). E-learning Readiness of Medical Educators: A Sample from Gazi University. Ankara Medical Journal, 18(2), 175-185. https://doi.org/10.17098/amj.435257

Cousera Inc. (2020). Retrieved from https://www.coursera.org

Creswell, J. W. (2007). Qualitative inquiry and research design: Choosing among five approaches. Thousand Oaks: Sage.

EdX Inc. (2020). Retrieved from https://www.edX.org

Hancock, R. D., \& Algozzine, B. (2006). Doing case study research. New York, USA: Teachers College Press.

Kantoğlu, B. (2012). Student satisfaction measurement in e-learning (PhD dissertation, Sakarya University).

Karasar, N. (2007). Araştırmalarda rapor hazırlama [Report preparation in research]. Ankara, Turkey: Nobel Yayıncilik.

Khan Academy. (2020). Retrieved from https://www.khanacademy.org.tr

Mayring, P. (2000). Qualitative content analysis. Online Journal Qualitative Social Research, 1(2), 1-10.

Merriam, S. B. (2013). Nitel araştırma: Desen ve uygulama için bir rehber [Qualitative Research: A Guide to Design and Implementation]. Ankara, Turkey: Nobel Yayın Dağıtım.

Metin, M. (2015). Kuramdan uygulamaya eğitimde bilimsel araştırma yöntemleri [Scientific research methods in education from theory to practice]. Ankara, Turkey: Pegem Akademi.

Miks, J., \& McIlwaine, J. (2020). Keeping the world's children learning through COVID-19. Retrieved from https://www.unicef.org/coronavirus/keeping-worlds-children-learning-through-covid-19

Miles, M. B., \& Huberman M. A. (1994). Qualitative data analysis: A sourcebook of new methods. Beverly Hills: Sage.

Millî Eğitim Bakanlı̆̆ı (n.d.). Retrieved from https://www.yegitek.meb.gov.tr 
Pınar, M. A., \& Akgül, G. (2020). The opinions of secondary school students about giving science courses with distance education during the covid-19 pandemic. Journal of Current Researches on Social Sciences, 10(2), 461-486. https://doi.org/10.26579/jocress.377

Rosenberg, M. J. (2000). E-learning: Strategies for delivering knowledge in the digital age. OH, USA: McGraw-Hill Companies.

Şahin, M., \& Erman, E. (2019). Evaluation of history teachers' opinions on the use of education information network (eba). MAKU Journal of Faculty of Education, 49, 256-275.

Seferoğlu, S. S. (2007). Öğretim teknolojileri ve materyal tasarımı [Instructional technologies and material design]. Ankara, Turkey: PegemA Yayınları. https://doi.org/10.14527/9786050370522

Soydal, İ, Alır, G., \& Ünal, Y. (2012). Are Turkish universities ready for e-learning: A case of Hacettepe University Faculty of Letters. Information Services \& Use, 31(3-4), 281-291. https://doi.org/10.3233/ISU-2012-0659

Soydan, Ş. (2011). Effectiveness of e-learning tools and an experiment of metacognitive skills approach (PhD dissertation, Marmara University).

Udedmy, Inc. (2020). Retrieved from https://www.udemy.com

UNICEF. (2020). UNICEF and Microsoft launch global learning platform to help address COVID-19 education crisis. Retrieved from https://www.unicef.org/turkey/en/press-releases/unicef-and-microsoft-launch-globallearning-platform-help-address-covid-19-education

University of Macau. (2018). Retrieved from https://ctle.um.edu.mo

Uşun, S. (2004). Bilgisayar destekli öğretimin temelleri [Fundamentals of computer assisted teaching]. İstanbul, Turkey: Nobel Yayınları.

Yalın, H. G. (2008). Internet temelli eğitim [Internet-based education]. Ankara, Turkey: Nobel Yayınları.

Yamamato, G. T., \& Altun, D. (2020). The coronavirus and the rising of online education. Journal of University Research, 3(1), 25-34. https://doi.org/10.32329/uad.711110

Yerli, M. S. (2018). Education information network (EBA) of the application of social studies in teaching student's academic success (MEd dissertation, Adiyaman University).

Yıldırım, A., \& Şimşek, H. (2011). Sosyal bilimlerde nitel araştırma yöntemleri [Qualitative research methods in the social sciences]. Ankara, Turkey: Seçkin Yayıncilık.

\section{Copyrights}

Copyright for this article is retained by the author(s), with first publication rights granted to the journal.

This is an open-access article distributed under the terms and conditions of the Creative Commons Attribution license (http://creativecommons.org/licenses/by/4.0/). 